\title{
Dar Prawdziwej Obywatelki Chorągiew z czasów napoleońskich
}

\author{
ANNA NADOLSKA \\ Muzeum Okręgowe im. Leona Wyczółkowskiego w Bydgoszczy \\ Uniwersytet Kazimierza Wielkiego w Bydgoszczy \\ e-mail: anna.nadolska@muzeum.bydgoszcz.pl \\ ORCID: 0000-0002-4063-7431
}

Keywords: Polish banner, Napoleonic era, Apolonia Ziółkowska, women’s social and patriotic activity, The Leon Wyczółkowski District Museum in Bydgoszcz

Słowa kluczowe: chorągiew polska, czasy napoleońskie, Apolonia Ziółkowska, działalność społeczno-patriotyczna kobiet, zbiory i wystawy, Muzeum Okręgowe w Bydgoszczy

\begin{abstract}
The Gift from a True Women Citizen. Polish Banner from the Napoleonic Era

This is the history of a banner of mass mobilization of Gniezno Voivodeship, precious memorabilia from the Napoleonic War, from the collection of The Leon Wyczółkowski District Museum in Bydgoszcz. The article tells not only the banner story but also the story of the 1806 Great Poland Uprising and the Bydgoszcz women's social and patriotic activity at the beginning of the $20^{\text {th }}$ century. The circumstances of the banner acquisition by the Bydgoszcz museum are also discussed as well as its modern use during museum exhibitions.
\end{abstract}

\begin{abstract}
Abstrakt
Artykuł traktuje o historii chorągwi pospolitego ruszenia województwa gnieźnieńskiego, cennej pamiątki z okresu wojen napoleońskich, która znajduje się w zbiorach bydgoskiego Muzeum Okręgowego im. Leona Wyczółkowskiego. W tę historię wpleciony został wątek zarówno powstania wielkopolskiego 1806 roku, jak i działalności społeczno-kulturalnej bydgoszczanek na początku XX wieku. Poruszono także kwestię pozyskania chorągwi do zasobu bydgoskiej placówki muzealnej oraz współczesnego wykorzystania jej w projektach wystawienniczych.
\end{abstract}


Napoleon Bonaparte na trwałe zapisał się w historii naszego narodu - w czasie gdy Polska była podzielona między zaborców utworzył Księstwo Warszawskie $^{1}$. Ta namiastka państwa funkcjonowała zaledwie kilka lat, lecz pamięć o niej i o jej twórcy przetrwała przez cały wiek XIX. Przekazywana z pokolenia na pokolenie opowieść o cesarzu Francuzów i chwalebnych czynach Polaków, którzy walczyli u jego boku, umacniała polską świadomość narodową oraz przekonanie o rychłym powrocie Rzeczypospolitej na mapę Europy².

Do utworzenia Księstwa Warszawskiego w dużym stopniu przyczynili się Wielkopolanie, którzy w 1806 roku wywołali powstanie przeciwko władzy pruskiej. Zakończyło się ono zwycięstwem, a Wielkopolska zasiliła polskimi rekrutami wojsko napoleońskie i miała swój udział w walkach o niepodległość ojczyzny³. W zbiorach Muzeum Okręgowego im. Leona Wyczółkowskiego w Bydgoszczy znajduje się niezwykła pamiątka związana z tamtymi wydarzeniami - mianowicie chorągiew pospolitego ruszenia województwa gnieźnieńskiego ${ }^{4}$. Jest to najstarszy, a zarazem najcenniejszy zabytek w bogatej kolekcji sztandarów i chorągwi organizacyjnych oraz cechowych z XIX-XX wieku, jaką posiada bydgoska placówka muzealna ${ }^{5}$. Mimo ogromnej wartości historycznej i regionalnej chorągiew ta w literaturze prawie nie funkcjonuje; notę na jej temat można odnaleźć zaledwie w dwóch katalogach wystaw: „Gdańsk napoleoński. Oblężenia 1807, 1813” (Muzeum Historyczne Miasta Gdańska, 2000) ${ }^{6}$ oraz „Od kościoła Klarysek po Wyspę Młyńską. Muzeum w Bydgoszczy 1923-2008” (Muzeum Okręgowe im. Leona Wyczółkowskiego w Bydgoszczy, 2008) ${ }^{7}$.

1 Zob. szerzej Archibald Gordon Macdonell, Napoleon i jego marszałkowie, tłum. Andrzej Nieuważny (Londyn: Wydawnictwo PULS, $1992^{2}$ ).

2 Anna Jabłońska i Dorota Matyaszczyk, „Napoleon i jego epoka w Wielkopolsce. XIV Europejskie Dni Dziedzictwa Kulturowego w Wielkopolsce 2006," Dostęp 16 stycznia 2020, http:// wtg-gniazdo.org/upload/opracowania/Napoleon_i_jego_epoka_w_Wielkopolsce.pdf.

3 Kazimierz Karolczak, „Polacy i ziemie polskie po III rozbiorze,” w Franciszek Leśniak, Kazimierz Karolczak, Wielka historia Polski 1696-1815, red. Marian Szulc (Kraków: PINNEX, 1998), 229-231; Jabłońska, Matyaszczyk, „Napoleon i jego epoka”.

4 Danuta Sójkowska, „Dwudziestolecie międzywojenne (1923-1939),” w Muzeum w Bydgoszczy. Katalog wystawy 26 września-28 grudnia 2008, red. Barbara Chojnacka, Danuta Sójkowska, i Michał Woźniak (Od Kościoła Klarysek po Wyspę Młyńską. Muzeum w Bydgoszczy 1923-2008, t. 2) (Bydgoszcz: Muzeum Okręgowe im. Leona Wyczółkowskiego, 2008), 150-151, poz. II 17.

5 Zdzisław Hojka, „Zbiory historyczne,” w Muzeum w Bydgoszczy. Katalog, 98.

6 Adam Paczuski, Gdańsk napoleoński. Oblężenia 1807, 1813. Katalog wystawy 22 lipca-13 sierpnia 2000 (Gdańsk: Muzeum Historyczne Miasta Gdańska, 2000), 80-81, poz. 6.

7 Zob. Sójkowska, „Dwudziestolecie,” 150-151, poz. II. 17. 
Celem niniejszego tekstu jest naświetlenie historii zabytkowej chorągwi z okresu napoleońskiego. Jej tło stanowi zarys dziejów pospolitego ruszenia rycerstwa w czasie powstania wielkopolskiego 1806 roku, z którym łączy się ufundowanie sztandaru. Zabytek ten przybliża zamieszczony w artykule pierwszy jego szczegółowy opis, a historię wzbogacają informacje o społeczno-patriotycznej aktywności Polek w Bydgoszczy na początku XX wieku oraz sylwetka jego właścicielki. Omówiona jest ponadto kwestia pozyskania chorągwi do zbiorów bydgoskiego muzeum oraz współczesne sposoby wykorzystania jej w projektach wystawienniczych. Odtwarzając dzieje chorągwi i ich związek z działalnością kobiet-patriotek w Wielkopolsce w pierwszych latach XIX wieku, następnie w Bydgoszczy w przededniu powrotu miasta do Polski w styczniu 1920 roku i później w Drugiej Rzeczypospolitej, autorka korzystała z archiwaliów i publikacji traktujących o powstaniu wielkopolskim 1806 roku oraz o historii Bydgoszczy w okresie napoleońskim i na początku XX wieku, a także z materiałów źródłowych i opracowań ukazujących udział polskich kobiet w życiu społeczno-narodowym oraz dotyczących bydgoskiego Muzeum Okręgowego. W niektórych kwestiach istotne okazały się wiadomości ogłaszane na łamach „Dziennika Bydgoskiego”. Jak wynika z przedstawionych rozważań, zabytkowa chorągiew ma duże znaczenie dla Bydgoszczy i regionu, a wartością dodaną jest w tym artykule interesujący wątek feministyczny, który scala opowieść o jej losach.

\section{Pospolite ruszenie szlachty w czasie powstania wielkopolskiego 1806 roku - zarys problematyki}

Na początku XIX wieku, w okresie wojen napoleońskich, Wielkopolska stanowiła część Królestwa Prus. W sierpniu 1805 roku powstała czwarta antyfrancuska koalicja z udziałem Prus. Po wygranej bitwie pod Jeną i Auerstädt Francuzi wkroczyli do Berlina. Gdy było już pewne, że zasięg walk rozszerzy się na ziemie dawnej Rzeczypospolitej, odżyły nadzieje na odrodzenie państwa polskiego. W obliczu wojny z Prusami Napoleon potrzebował rekrutów, a dzięki obietnicy wsparcia sprawy polskiej mógł liczyć na polskich ochotników. Obligując gen. Jana Henryka Dąbrowskiego do wzniecenia powstania w Wielkopolsce i poboru nowych żołnierzy do armii napoleońskiej ${ }^{8}$, Napo-

8 Karolczak, „Polacy i ziemie polskie,” 227-229; Jan Wąsicki, „Powstanie 1806/1807 roku,” w Dzieje Wielkopolski, t. 2 Lata 1793-1918, red. Witold Jakóbczyk (Poznań: Wydawnictwo Poznańskie, 1973), 45. 
leon chciał przekonać się „czy Polacy są warci jego opieki i czy to [...] zgadza się z powszechnym życzeniem narodu”. Swoją decyzję co do „nadania politycznego bytu Polsce" uzależniał więc od postawy Wielkopolan'. W pierwszej odezwie do Polaków wzywającej do wsparcia Francuzów i walki o wolność, wydanej na polecenie cesarza przez generałów Jana H. Dąbrowskiego i Józefa Wybickiego 3 listopada 1806 roku w Berlinie, ogłaszano i agitowano: „Napoleon Wielki, niezwyciężony, wchodzi w trzykroć sto tysięcy do Polski. Nie zgłębiajmy tajemnicy zamysłów, starajmy się być gotowymi jego wspaniałomyślności. Obaczę, powiedział nam, obaczę, jeżeli Polacy gotowi są być narodem. Idę do Poznania, tam się pierwsze moje zawiążą wyobrażenia o jego wartości. Polacy! Od Was więc zawisło istnieć i mieć Ojczyznę - wasz zemściciel, wasz stwórca się zjawił"10.

Już 6 listopada obaj dowódcy przybyli do Poznania w celu zorganizowania - z pełnomocnictwa cesarza - polskiej administracji oraz wojska. Wkrótce wyszedł rozkaz o poborze rekrutów (,jeden rekrut z każdych dziesięciu dymów"), natomiast szlachta z województw wielkopolskich ${ }^{11}$ położonych na lewym brzegu Wisły została „Uniwersałem na pospolitą obronę” (z 2 grudnia 1806 roku) wezwana do pospolitego ruszenia „jako instytucji polskiej” ${ }^{12}$. Dokument podpisał były wojewoda gnieźnieński, Józef Radzimiński herbu Lubicz, który apelował: „Wzywam was wszystkich obywatelów województw wielkopolskich, jako jeden pozostały wojewoda, do pospolitej obrony. Niech każdy, kto może władać orężem, siada na koń, a najmniej niech z każdego domu jeden z synów czy braci zbrojno pod chorągwią ojczyzny na koniu stawa i jednego z sobą lub dwóch pocztowych wiedzie ubranych w wojewódzkim mundurze, krojem kurtek i czapek wojskowych"13. Za zlekceważenie naka-

9 Jan Pachoński, Generał Jan Henryk Dąbrowski 1755-1818 (Warszawa: Wydawnictwo MON, 1981), 338.

10 Pachoński, Generał Jan Henryk Dąbrowski, 338; Karol Olejnik, „Rok 1806 w Wielkopolsce,” Kronika Miasta Poznania 65, nr 3 (1997): 52; zob. też Marian Kallas, „W czasach Księstwa Warszawskiego,” w Historia Bydgoszczy, t. 1 do roku 1920, red. Marian Biskup (Warszawa-Poznań: Bydgoskie Towarzystwo Naukowe, 1991): 419.

11 Województwa wielkopolskie: pomorskie, malborskie, kujawskie, inowrocławskie, gnieźnieńskie, poznańskie, kaliskie, część krakowskiego, sieradzkie, ziemia wieluńska, łęczyckie, rawskie i mazowieckie.

12 Archiwum Wybickiego, t. 2 (1802-1822), zebr. i wyd. Adam M. Skałkowski (Gdańsk: Nakładem Towarzystwa Przyjaciół Nauki i Sztuki w Gdańsku z zasiłku Ministerstwa Szkół Wyższych i Nauki, 1950), 58-59.

13 Archiwum Wybickiego, 59; Jan Wąsicki, Powstanie 1806 roku w Wielkopolsce (Poznań: Wydawnictwo Poznańskie, 1958), 77. 
zu uniwersału groziły surowe kary. Zgodnie z rozkazem uzbrojona szlachta 15 grudnia miała się stawić w miastach wojewódzkich (dla rycerstwa województwa gnieźnieńskiego miejscem konsolidacji było Gniezno), stamtąd dotrzeć na 25 grudnia pod Łowicz, a potem w całości podążyć w kierunku Warszawy ${ }^{14}$. Na czele zebranych sił stanął generał Dąbrowski ${ }^{15}$, a dowództwo pospolitego ruszenia poszczególnych województw objęli rotmistrzowie - dla województwa gnieźnieńskiego był to Rydzyński; dowódcy podzielili szlachtę na chorągwie ${ }^{16}$. Sztandar województwa gnieźnieńskiego ufundowano 21 grudnia. Jak podaje Jan Wąsicki, „Każdy rycerz miał obowiązek utrzymania siebie i swojego pocztowego aż do 1 lutego 1807 roku. Władze wojskowe i cywilne miały dostarczyć jedynie furażu dla koni”. Biskup poznański Ignacy hrabia Nałęcz w liście z 28 grudnia powiadamiał: „Siła zbrojna Województwa naszego, ku powszechnej obronie zebrana, już z domów swych i Stolicy ruszyła, Poświęcone w Obliczu Boga chorągwie, na czele wybranego ludu, rozwinięte zostały. Odważni rycerze opuścili z chęcią dziedzinę, majątki, dzieci i najmilszą familią" ${ }^{17}$. Uroczystość zaprzysiężenia zwołanego rycerstwa odbyła się 1 stycznia 1807 roku przy udziale gen. Dąbrowskiego. Głównodowodzący w swoim przemówieniu podkreślił: „Rok 1807 jest pierwszy, w którym każdy z was życie swoje poczyna, bo kto ojczyzny swej nie miał, tego można w liczbę umarłych policzyć. Ta ziemia, po której dziś wolni chodzicie, dopiero od tego momentu poznała prawdziwe swe dzieci, kiedy was widzi zebranych na ochronę swoją". Chwilę później każdy szlachcic przysięgał: „posłuszny do zgonu rozkazom Wielkiego Napoleona o swobodę i całość Ojczyzny aż do przelania ostatniej kropli krwi mojej walczyć będę"18.

Do połowy stycznia 1807 roku udało się zgromadzić pod bronią ponad cztery tysiące konnej szlachty z wielkopolskiego pospolitego ruszenia oraz „20 tys. żołnierzy wziętych drogą poboru rekruta” ${ }^{19}$. Według tekstu Jana Wąsickiego, „pełne zapału pospolite ruszenie, jeszcze nie zorganizowane i nie

14 Wąsicki, Powstanie 1806 roku, 79; Wąsicki, „Powstanie 1806/1807 roku,” 50.

15 Janusz Staszewski, „Organizacja dywizji poznańskiej w 1806 r.”, Roczniki Historyczne 9 (1933): 72 [2]; Olejnik, „Rok 1806,” 61-62; Pachoński, Generał Jan Henryk Dąbrowski, 350, 356; Karolczak, „Polacy i ziemie polskie,” 229-230; por. Wąsicki, Powstanie 1806 roku, 78.

16 Wąsicki, Powstanie 1806 roku, 79.

17 Archiwum Wybickiego, 77.

18 Wąsicki, Powstanie 1806 roku, 81.

19 Staszewski, „Organizacja dywizji,” 72 [2]; Olejnik, „Rok 1806,” 61-62; Pachoński, Generał Jan Henryk Dąbrowski, 350, 356; Karolczak, „Polacy i ziemie polskie,” 229-230; por. Wąsicki, Powstanie 1806 roku, 78. 
ujęte w karby dyscypliny, poszło pod komendę generała Niemojewskiego i pułkownika Wincentego Krasińskiego i osłaniać miało leże zimowe Wielkiej Armii. Najbardziej wartościowe jego oddziały przeobraziły się następnie w pułki kawalerii narodowej. [...] Część pospolitego ruszenia walczyła już pod dowództwem A. Kosińskiego z podjazdami nieprzyjaciela w okolicy Bydgoszczy. Wkrótce też utworzony został z pospolitego ruszenia specjalny korpus jazdy powstańczej związany z legią Dąbrowskiego" ${ }^{20}$. Nowo powstała armia wzięła udział między innymi w walkach o Tczew i Gdańsk, a Dąbrowski 20 stycznia znalazł się w Bydgoszczy ${ }^{21}$. Jak jednak podkreśla Karol Olejnik, mimo niewątpliwego sukcesu Wielkopolan, którzy ochoczo odpowiedzieli na zwołanie pospolitego ruszenia, „dokonania organizacyjne na polu formowania podstaw narodowej siły zbrojnej muszą także być ocenione w kontekście ogromnego ciężaru, jaki spadł na barki mieszkańców tej ziemi, w chwili gdy wkroczyła tutaj armia francuska”22 (il. 1).

Było to pierwsze powstanie wygrane przez Polaków. Odtąd cesarz „zaczął poważniej traktować sprawę polską, postrzegając ją nie tylko jako problem wojskowy”23. Tym samym została otwarta prosta droga do utworzenia - tuż po dalszych walkach i zawarciu przez Francję i Rosję pokoju w Tylży - Księstwa Warszawskiego ${ }^{24}$. Dzieło to mogło się urzeczywistnić dzięki Wielkopolanom - ich wsparciu osobowemu, ekonomicznemu i militarnemu ${ }^{25}$.

\section{Charakterystyka zabytku}

Opis i analizę zabytkowej chorągwi pospolitego ruszenia województwa gnieźnieńskiego z kolekcji Muzeum Okręgowego w Bydgoszczy (nr inw. MOB H-897; il. 2-3) warto poprzedzić definicją sztandaru. Według Kazimierza Satora „sztandar należał do symboli narodowych, znaków tożsamości, honoru i godności narodowej. Kumulował w sobie uczucia patriotyczne i treści historyczne. Był symbolem wierności ojczyźnie, honoru i męstwa żołnierskiego”²6.

20 Wąsicki, Powstanie 1806 roku, 82.

21 Pachoński, Generał Jan Henryk Dąbrowski, 357, 359-360; Kallas, „W czasach Księstwa Warszawskiego," 424-425.

22 Olejnik, „Rok 1806,” 63.

23 Karolczak, „Polacy i ziemie polskie,” 230-231.

24 Pachoński, Generał Jan Henryk Dąbrowski, 379.

25 Jabłońska i Matyaszczyk, „Napoleon i jego epoka”.

26 Kazimierz Satora, Na tropach wrześniowych sztandarów (Warszawa: Związek Kombatantów RP i Byłych Więźniów Politycznych Warszawa Śródmieście i Fundacja Moje Wojenne Dzieciństwo, 2001): 11. 
Omawiana chorągiew, ufundowana na terenie Wielkopolski w 1806 roku, została wykonana z jedwabiu oraz złotej frędzli i ozdobiona haftem płaskim i wypukłym sporządzonym nićmi srebrnymi i jedwabnymi; brakuje jej drzewca ${ }^{27}$.

Płatem chorągwi jest cienki jedwabny materiał w kształcie prostokąta o wymiarach 82,0 × 58,5 cm, z lekko zmodyfikowanym jaskółczym ogonem na krótszym boku (chorągiew zakończona dwoma językami - nieostrymi, zaokrąglonymi, „między którymi znajduje się wolna przestrzeń w kształcie trójkąta” ${ }^{28}$ ). Krawędzie chorągwi, z wyjątkiem boku przytwierdzanego do drzewca, są obszyte złotą frędzlą. Awers płata jest w kolorze karminowym. W jego górnej części wyhaftowano stanisławowskiego orła $\mathrm{z}$ berłem i jabłkiem królewskim w szponach ${ }^{29}$ (il. 4), pod nim zaś napis: „Zwyciężyć albo umrzeć za Oyczyzny Sprawę / Każdy winien kto Kocha Kray, Honor i Sławę / Gdy nas Napoleona hasło na bóy wzywa / Daie Sztandar bo więcey dać nie ma Prawdziwa / Obywatelka” (il. 5). Przy trzech krawędziach płata wyhaftowany jest zygzakowaty szlaczek. Rewers płata jest w kolorze jasnobeżowym. W jego górnej części wyhaftowano Oko Opatrzności Bożej, pod spodem napis minuskułą: „Sztandar Rycerstwu / Województwa Gnieźnieńskiego / ofiarowany D. 15º Grudnia / 1806 Roku" (il. 6). Trzy krawędzie zdobi haftowany zygzakowaty szlaczek.

W 1975 roku płat chorągwi był mocno przybrudzony, a jego strona główna bardzo zniszczona, z licznymi pęknięciami. W miejscu mocowania drzewca znajdowały się dziurki, najprawdopodobniej po metalowych kółeczkach (il. 7), a na odwrociu płata kilka pęknięć materiału (il. 8). W 1982 roku chorągiew poddano zabiegom konserwatorskim. Została wtedy doszyta tuleja do mocowania drzewca, której pierwotnie obiekt nie posiadał. Jego obecny stan jest dobry ${ }^{30}$.

Chorągiew została ufundowana w związku z wydarzeniami, jakie wywołał wydany w 1806 roku „Uniwersał na pospolitą obronę” skierowany do wiel-

27 Sójkowska, „Dwudziestolecie,” 150-151, poz. II. 17.

28 Bydgoszcz, Muzeum Okręgowe im. Leona Wyczółkowskiego (dalej: MOB), Dział Historii, Sztandar Rycerstwu Województwa Gnieźnieńskiego ofiarowany D. 15go Grudnia 1806 roku, nr inw. MOB H-897, karta naukowa zabytku, oprac. Gabriela Bedrij, Bydgoszcz 1975; „Weksylologia”, Album Polski, Instytut Heraldyczno-Weksylologiczny, Dostęp 16 stycznia 2020, http://www.albumpolski.pl/IHW_WWW/index.php?act=view\&ktg=27 \&idt=134.

29 Orzeł ten przypomina godło Księstwa Warszawskiego (orzeł biały w koronie z insygniami w szponach) utworzonego w $1807 \mathrm{r}$.

30 MOB, Dział Historii, Sztandar Rycerstwu Województwa Gnieźnieńskiego ofiarowany D. 15go Grudnia 1806 roku, nr inw. MOB H-897, karta naukowa zabytku, oprac. Gabriela Bedrij, Bydgoszcz 1975; zob. też Jabłońska i Matyaszczyk, „Napoleon i jego epoka”. 
kopolskiej szlachty ${ }^{31}$. Wskazuje na to nie tylko data wyhaftowana na płacie, tożsama z terminem stawienia się szlachty województw wielkopolskich, ale także oba umieszczone pod symbolami napisy. Pierwszy z nich głosi, że każdy patriota powinien ruszyć w bój na wezwanie Napoleona, a drugi informuje, że sztandar został ofiarowany rycerstwu województwa gnieźnieńskiego. Wyraz „rycerstwo” odnosi się tu do szlachty, województwo gnieźnieńskie zaś funkcjonowało na terenie Wielkopolski w latach 1768-1793, w jego skład wchodziły powiaty gnieźnieński, kcyński i nakielski ${ }^{32}$. Gnieźnieńska szlachta otrzymała sztandar 15 grudnia 1806 roku, a z przywołanego listu biskupa poznańskiego wynika, że już 28 grudnia wszystkie chorągwie województw wielkopolskich były poświęcone ${ }^{33}$. Napis na awersie informuje również, że sztandar podarowała kobieta - miał to być jej osobisty wkład w odzyskanie przez Polskę wolności. „Prawdziwa Obywatelka”, nie mogąc wziąć udziału w walce (zakazywało tego prawo i tradycja), chciała przysłużyć się sprawie polskiej w inny - dostępny ówczesnej kobiecie, ale także praktyczny sposób. Czy wielkopolska fundatorka sama wykonała chorągiew, czy zleciła komuś tę czynność? Tego nie da się rozstrzygnąć na podstawie wyhaftowanego na płacie napisu. Nie ulega jednak wątpliwości, że przedmiot ten wytworzyły damskie ręce, ponieważ hafciarstwo przez stulecia było wyłączną domeną kobiet $^{34}$. Ręce te działały szybko, sprawnie, w ciągu zaledwie kilku dni - zaczęły pracę po 2 grudnia, czyli po ogłoszeniu uniwersału, a skończyły najpóźniej 15 grudnia, czyli w dniu przybycia wezwanego rycerstwa do Gniezna.

Inna chorągiew z czasów napoleońskich wykonana przez Wielkopolankę znajduje się w Muzeum Wojska Polskiego w Warszawie. Pochodzi ona z 1807 roku i ma upamiętniać powstanie Księstwa Warszawskiego. Widnieje na niej wizerunek orła w koronie z insygniami i napis: „Wojsko / Polskie / 1807”. Za jej twórczynię uważa się Barbarę z Chłapowskich Dąbrowską, żonę gen. Dąbrowskiego ${ }^{35}$.

31 Pachoński, Generał Jan Henryk Dąbrowski, 350, 356; Karolczak, „Polacy i ziemie polskie,” 229-230.

32 Zygmunt Gloger, „Geografia historyczna ziem dawnej Polski. Województwo Kaliskie i Gnieźnieńskie”, Dostęp 21 listopada 2020, https://iterat.ug.edu.pl/glogre/0018.htm.

33 Archiwum Wybickiego, 77.

34 Szerzej zob. Anna Kowalczyk, Brakująca połowa dziejów. Krótka historia kobiet na ziemiach polskich (Warszawa: Wydawnictwo WAB, 2018), 178.

35 Korespondencja z Jarosławem Łuczakiem, kierownikiem Wielkopolskiego Muzeum Wojskowego w Poznaniu; „Kalendarium dziejów oręża polskiego. 7 lipca 1807 Powstanie Księstwa Warszawskiego", Dostęp 18 lutego 2020, http://www.muzeumwp.pl/kalendarium/07-07/. 


\section{„Sztandar polski” \\ a działalność społeczno-patriotyczna bydgoszczanek}

Na fundatorce chorągwi i być może artystce-amatorce, która ją wykonała, nie kończy się kobiecy wątek w dziejach tego zabytku. Dalsze jego losy były związane zarówno z aktywnością kobiet na polu społecznym, jak i z miastem Bydgoszczą. W czasie pierwszej wojny światowej oraz w końcu 1919 roku, czyli w okresie poprzedzającym powrót tego miasta do Macierzy ${ }^{36}$, tutejsze Polki wykorzystywały dawny sztandar pospolitego ruszenia jako symbol zwycięskich działań do budzenia postaw patriotycznych wśród polskich mieszkańców oraz w podejmowanych akcjach społeczno-charytatywnych. Polskie bydgoszczanki, zrzeszone w różnorodnych stowarzyszeniach, były bardzo aktywne na niwie narodowej: organizowały zbiórki pieniężne na wyznaczone cele, spotkania i wieczornice patriotyczne, odczyty, amatorskie przedstawienia teatralne, wystawy prac kobiecych ${ }^{37}$. Podobnie jak dla ogółu Polek w zaborze pruskim, nadrzędną sprawą, a wręcz kobiecą powinnością w tym czasie było dla nich podtrzymywanie polskiej świadomości narodowej ${ }^{38}$.

W XIX wieku oraz na przełomie stuleci XIX i XX Wielkopolanie pieczołowicie przechowywali wszelkie pamiątki napoleońskie, traktując je wręcz jak relikwie narodowe. W Poznańskiem mieszkało wielu weteranów napoleońskiej epopei, co sprzyjało kultywowaniu pamięci o dokonaniach cesarza Francuzów w kwestii polskiej39. Nic więc dziwnego, że bydgoszczanki otoczyły szczególną opieką sztandar - pamiątkę z czasów Bonapartego, która dodatkowo świadczyła o zasługach Polaków na rzecz wolności ojczyzny. Jako okazję do zaprezentowania tej wyjątkowej chorągwi szerszej publiczności wykorzystały trwającą od 8 grudnia 1917 roku pierwszą wystawę prac ko-

36 Jerzy Wojciak, „Pod pruskim zaborem 1815-1920”, w Ryszard Kabaciński, Wojciech Kotowski, i Jerzy Wojciak, Bydgoszcz: Zarys dziejów (Bydgoszcz: WSiP, 1980), 140, 143.

37 Agnieszka Baszko, „Organizowanie się kobiet polskich w Poznańskiem na przełomie XIX i XX wieku”, w Działaczki społeczne, feministki, obywatelki... Samoorganizowanie się kobiet na ziemiach polskich do 1918 roku (na tle porównawczym), red. Agnieszka Janiak-Jasińska, Katarzyna Sierakowska, i Andrzej Szwarc (Warszawa: Wydawnictwo Neriton, 2008), 288.

38 Rudolf Jaworski, „Kilka refleksji nad dziejami Wielkopolanek w XIX i na początku XX wieku,” w Kobieta i społeczeństwo na ziemiach polskich w XIX wieku, red. Anna Żarnowska i Andrzej Szwarc (Warszawa: Wydawnictwo DiG, 1990), 26; Natalia Stegmann, „Wielkopolskie wzorce kobiecej aktywności społecznej w życiu codziennym kobiet na przełomie XIX i XX wieku," w Kobieta i kultura życia codziennego. Wiek XIX i XX, red. Anna Żarnowska i Andrzej Szwarc (Warszawa: Wydawnictwo DiG, 1997), 365-366.

39 Zygmunt Dolczewski, „Pamiątki napoleońskie w zbiorach poznańskiego Muzeum Sztuk Użytkowych,” Kronika Miasta Poznania 65, nr 3 (1997): 149. 
biet z Bydgoszczy i okolic. Ekspozycję tych wyrobów w lokalu na Zbożowym Rynku 5 zorganizowało miejscowe koło ziemianek z Marią Palędzką na czele. Dochód z wystawy miał być „przekazany dla bezdomnych naszych rodaków spoza kordonu”. Obok współczesnych pejzaży, portretów, rysunków kredką, kilimów, gobelinów, serwet, obrusów, fartuszka, żakietu damskiego, ręcznie malowanych filiżanek, pokazano także starsze eksponaty, takie jak pisana ręcznie książeczka do nabożeństwa z 1845 roku i poduszka z 1817 roku. Na niektórych artefaktach widniały motywy patriotyczne, na przykład na kilimie zakopiańskim i poduszce były wyhaftowane figury orła białego ${ }^{40}$.

Wystawę prac kobiecych omówiła w obszernym, dwuczęściowym artykule opublikowanym w „Dzienniku Bydgoskim” Stefania Tuchołkowa, bydgoska literatka, zasłużona działaczka społeczno-kulturalna, przewodnicząca Czytelni dla Kobiet ${ }^{41}$. W końcowej części recenzji przybliżyła czytelnikom najcenniejszy obiekt prezentowany na tej ekspozycji, a mianowicie omawianą tu chorągiew z czasów napoleońskich ${ }^{42}$. Autorka - bez wątpienia chorągiew była dla niej narodową relikwią - zamieściła opis zabytku sprzed stu jedenastu lat, zacytowała treść wyhaftowanych na nim napisów i naszkicowała podniosłą atmosferę, jaka panowała wśród polskich żołnierzy walczących u boku cesarza Francuzów pod tym sztandarem. Namawiając czytelników gazety do zapoznania się z ekspozycją, zwracała uwagę na ten właśnie obiekt i związane z nim emocje: „Dla tego samego sztandaru, dla ożywienia serc w krynicy wielkich wspomnień, jakie to wyblakłe płótno i haft poczerniały we widzu budzą - warto zwiedzić lokale wystawowe"43.

Po dwóch latach ukazał się - również w „Dzienniku Bydgoskim” - kolejny artykuł, który rzuca światło na historię chorągwi i na jej ponowne wykorzystanie „w słusznej sprawie” przez bydgoszczankę. Dowiadujemy się z niego, że właścicielką zabytkowego obiektu - chorągwi z białym orłem, „który skrzydła swe rozpinał do lotu nad polami bitew chwały" - jest Apolonia Ziółkowska, która za drobną opłatą chce go pokazywać u siebie w domu przy ul. Starofarnej 5. Działaczka społeczna i narodowa próbowała w ten sposób po-

40 Stefanja Tuchołkowa, „Pierwsza wystawa prac kobiecych w Bydgoszczy,” Dziennik Bydgoski, 12 grudnia, 1917, 2-3; Stefanja Tuchołkowa, „Pierwsza wystawa prac kobiecych w Bydgoszczy,” Dziennik Bydgoski, 13 grudnia 1917, 2-3.

41 Anna Nadolska, „Ziemianka w służbie Bydgoszczy. Kulturalna, społeczna i narodowa działalność Stefanii Tuchołkowej na początku XX wieku," Kronika Bydgoska 39 (2018): 85-102.

42 Tuchołkowa, „Pierwsza wystawa,” 13 grudnia 1917, 3.

43 Tuchołkowa, „Pierwsza wystawa,” 13 grudnia 1917, 3. 
zyskać dodatkowe fundusze na cele Opieki Dworcowej ${ }^{44}$, organizacji wspierającej samotnie podróżujące młode kobiety i zapewniającej im tanie noclegi ${ }^{45}$. Co ciekawe, nieznany autor (autorka?) tekstu opublikowanego 29 listopada ponagla osoby zainteresowane oględzinami, ponieważ Ziółkowska planuje „świeżo odnowiony w klasztorku sióstr” sztandar przekazać 15 grudnia 1919 roku - w sto trzynastą rocznicę jego ufundowania - „na wieczną pamiątkę” polskiemu muzeum w Bydgoszczy ${ }^{46}$. O ile informacja, że działaczka chciała podarować zabytek, nie budzi wątpliwości, o tyle niezrozumiałe jest, że miałaby to uczynić w końcu 1919 roku, kiedy w mieście nad Brdą nie było jeszcze polskiej placówki muzealnej ${ }^{47}$.

Apolonia Ziółkowska była bydgoską patriotką i „kobietą czynu”. Wraz z siostrą Anielą prowadziła sklep w Bydgoszczy i wykazywała się aktywnością na polu społecznym. Jeszcze w okresie pruskim organizowała akcje charytatywne, a także zajmowała się edukacją biednych dzieci i opracowywaniem polskich elementarzy. W 1918/1919 roku wzięła udział w powstaniu wielkopolskim. Razem ze Stefanią Tuchołkową i Wincentyną Teskową należała do zakonspirowanej komórki Polskiej Rady Ludowej na miasto Bydgoszcz i przedmieścia, której zadaniem była rekrutacja ochotników do szeregów powstańczych, przeprawianie młodych mężczyzn przez linię walk oraz zakup i przemyt broni. Za pieniądze zebrane od bydgoszczan lokalna patriotka dożywiała więzionych Polaków. W 1918 roku współzałożyła i prowadziła Opiekę Dworcową ${ }^{48}$.

Działalność Apolonii Ziółkowskiej nie zakończyła się wraz z powrotem Bydgoszczy do Polski w styczniu 1920 roku. W okresie międzywojennym była konspiratorka pełniła funkcję członka Zarządu Bydgoskiego Koła dla Badań nad Historią powstania wielkopolskiego 1918/1919 roku. Stowarzyszenie to zajmowało się - obok gromadzenia relacji, archiwaliów i pamiątek oraz badania przebiegu poszczególnych potyczek - także popularyzowaniem wśród bydgoszczan i w szerszych kręgach wiedzy na temat wielkopolskiego zrywu niepodległościowego. Reprezentując dział charytatywny Koła, Ziółkow-

44 „Chorągiew polska z r. 1806,” Dziennik Bydgoski, 29 listopada 1919, 2.

45 Anna Nadolska, „Konspiracja w spódnicy. Bydgoszczanki w wielkopolskim zrywie niepodległościowym 1918/1919," Kronika Bydgoska 38 (2017): 227.

46 "Chorągiew polska”, 2.

47 Zdzisław Hojka, Muzeum w Bydgoszczy. Dzieje i zbiory (Od Kościoła Klarysek po Wyspę Młyńską. Muzeum w Bydgoszczy 1923-2008, red. Michał Woźniak, t. 1) (Bydgoszcz: Muzeum Okręgowe im. Leona Wyczółkowskiego, 2008), 14.

48 Nadolska, „Konspiracja w spódnicy,” 225-229. 
ska prowadziła akcje dobroczynne, ale także wygłaszała referaty dotyczące powstania ${ }^{49}$. Tajemnicą pozostaje, kiedy i w jaki sposób bydgoska działaczka weszła w posiadanie cennego sztandaru pospolitego ruszenia szlachty z 1806 roku.

\section{Pamiątka z czasów napoleońskich w zbiorach bydgoskiego Muzeum}

W styczniu 1920 roku Bydgoszcz wróciła w granice polskiego państwa, a trzy lata później powołano do życia Muzeum Miejskie. W chwili otwarcia w placówce znajdowały się wyłącznie przejęte zabytki gromadzone od końca XIX wieku przez bydgoskie Towarzystwo Niemieckie. Z tego względu zbiory były sukcesywnie powiększane przede wszystkim o rodzime pamiątki, archiwalia oraz dzieła sztuki. Większość obiektów, które muzeum pozyskało w tym czasie, pochodziła z darowizn. Mniejszą część stanowiły depozyty i - w miarę możliwości finansowych instytucji - muzealia zakupione ${ }^{50}$.

Na przełomie lat 1923 i 1924 zbiory Muzeum Miejskiego wzbogaciły się o wspaniały dar w postaci zabytkowej chorągwi. Ofiarodawczyni, Apolonia Ziółkowska, spełniła obietnicę z końca 1919 roku i podarowała młodemu polskiemu muzeum cenny artefakt z czasów napoleońskich ${ }^{51}$. Nie była to jedyna darowizna bydgoskiej patriotki na rzecz nowo powstałej instytucji kultury - Ziółkowska przekazała do zbiorów muzealnych również chorągiew z powstania wielkopolskiego 1918/1919 $\mathrm{roku}^{52}$. Oba obiekty do dziś pozostają w zasobie Muzeum Okręgowego im. Leona Wyczółkowskiego w Bydgoszczy (taką nazwę bydgoska placówka nosi od lat siedemdziesiątych XX wieku).

Chorągiew pospolitego ruszenia województwa gnieźnieńskiego była prezentowana na kilku historycznych wystawach czasowych, w tym także niezwykle prestiżowych dla muzeum i miasta. W 1991 roku chorągiew użyczono

49 „Pierwsze posiedzenie zarządu bydgoskiego Koła dla badań nad historią powstania Wlkp z 1918-19 r.,” Dziennik Bydgoski, 20 stycznia1927, 5; Nadolska, „Konspiracja w spódnicy,” 231.

50 Hojka, Muzeum w Bydgoszczy, 11-22.

51 Sójkowska, „Dwudziestolecie,” 150-151, poz. II. 17.

52 Anna Nadolska, „Obiekt miesiąca. Chorągiew powstania wielkopolskiego,” Bydgoski Informator Kulturalny 44, nr 11 (499) (2018): 28; obiekt był prezentowany na wystawie jubileuszowej „Niepodległa Polska. 1918 rok” w MOB z okazji 100. rocznicy odzyskania przez Polskę niepodległości (11 XI 2018-12 V 2019, kuratorzy wystawy: Anna Nadolska i Dariusz Leśniewski), zob. Anna Nadolska, „Niepodległa Polska. 1918 rok”, Dostęp: 21 listopada 2020, http://muzeum.bydgoszcz.pl/wystawy/id,257,0,0,Niepodlegla-Polska-1918-rok. 
na ekspozycję Muzeum Tradycji Pomorskiego Okręgu Wojskowego (obecnie Muzeum Wojsk Lądowych w Bydgoszczy), a trzy lata później do Muzeum Okręgowego w Pile ${ }^{53}$. Następnie pokazano ją na wystawie „Gdańsk napoleoński”, zorganizowanej w roku 2000 przez Muzeum Historyczne Miasta Gdańska (obecnie Muzeum Gdańska); w towarzyszącym wystawie katalogu ukazała się nota z opisem chorągwi z czasów napoleońskich ${ }^{54}$. Z kolei w 2008 roku świętujące osiemdziesiątą piątą rocznicę powstania bydgoskie Muzeum Okręgowe wystawiło obiekt na jubileuszowej ekspozycji „Od kościoła Klarysek po Wyspę Młyńską. Muzeum w Bydgoszczy 1923-2008. Dzieje i zbiory”, nagrodzonej w konkursie na Wydarzenie Muzealne Roku Sybilla 2008. W związku z tą wystawą przygotowano obszerny katalog, w którym opisano najcenniejsze zabytki muzeum - a wśród nich nie mogło zabraknąć chorągwi z okresu napoleońskiego, daru Apolonii Ziółkowskiej ${ }^{55}$.

Uczestnicząc w tych ekspozycjach bydgoska instytucja kultury upowszechnia wiedzę na temat wydarzeń wielkopolskich z 1806 roku oraz związanej z nimi chorągwi, a także kontynuuje tradycję zapoczątkowaną przez bydgoszczanki z początku XX wieku, wystawiając zabytek na widok publiczny i realizując cele edukacji patriotycznej.

\section{Podsumowanie}

Omówiona chorągiew pospolitego ruszenia województwa gnieźnieńskiego stanowi niezwykłą pamiątkę udziału Wielkopolan w walkach o niepodległość u boku cesarza Francuzów Napoleona Bonaparte. Jednocześnie z tym sztandarem z wizerunkiem białego orła, „który skrzydła swe rozpinał do lotu nad polami bitew chwały”, na przestrzeni stulecia związane były kobiety. Chorągiew powstała dzięki pierwszej z nich, bezimiennej „Prawdziwej Obywatelce”. W okresie poprzedzającym powrót Bydgoszczy do Macierzy w 1920 roku kobiety przechowywały, ale także wykorzystały ten zabytek do krzewienia postaw patriotycznych wśród tutejszych Polaków. Z kolei w odrodzonej Polsce kobieta, działaczka społeczna i narodowa, podarowała chorągiew nowo otwartemu Muzeum Miejskiemu „na wieczną pamiątkę”. Ponadto dwie Polki żyjące w skrajnych latach dzielącego je stulecia - anonimowa fundatorka

53 MOB, Dział Historii, Sztandar Rycerstwu Województwa Gnieźnieńskiego ofiarowany D. 15go Grudnia 1806 roku, nr inw. MOB H-897 (zob. przyp. 30).

54 Paczuski, Gdańsk napoleoński, 80-81, poz. 6.

55 Sójkowska, „Dwudziestolecie,” 150-151, poz. II. 17. 
obiektu i jego późniejsza ofiarodawczyni Apolonia Ziółkowska - miały związek z powstaniami wielkopolskimi: pierwsza ze zrywem niepodległościowym w 1806 roku, druga z insurekcją w roku 1918/1919. Chorągiew zaś, będąc produktem kobiecych rąk, stała się elementem kobiecego wkładu w dzieło odrodzenia Polski.

Tradycję przekazywania przez kobiety sztandarów dla Wojska Polskiego kultywowano w okresie międzywojennym. Ziemianki i aktywistki społeczne organizowały zbiórki pieniędzy na sztandary dla okolicznych pułków, w tym dla 16. Pułku Ułanów Wielkopolskich ${ }^{56}$. Zasłużone dla sprawy narodowej kobiety zostawały też matkami chrzestnymi sztandarów poszczególnych jednostek, na przykład wspomniana tu Stefania Tuchołkowa była matką chrzestną 62. Pułku Piechoty ${ }^{57}$.

Obecnie znajdująca się w bydgoskich zbiorach muzealnych chorągiew z czasów napoleońskich służy do celów naukowych, edukacyjnych i upowszechnieniowych. Znaczenie tego zabytkowego artefaktu trafnie oddają dotyczące go słowa Stefanii Tuchołkowej z 1917 roku: „Ci, którzy pod nim walczyli, dawno w proch się już rozsypali, lecz sztandar sam pozostał nietkniętym i niezniszczalnym jest symbol, który on przedstawia"58.

56 Sztandar ofiarowały pułkowi 18 XI 1919 r. członkinie Koła Ziemianek Wlkp., XV-lecie 16/2 Pułku Ułanów Wielkopolskich 1919-1934. Jednodniówka, oprac. Franciszek Małek i Czesław Dmochowski, 1934, 19.

57 Nadolska, „Ziemianka w służbie Bydgoszczy,” 92.

58 Tuchołkowa, „Pierwsza wystawa,” 13 grudnia 1917, 3. 


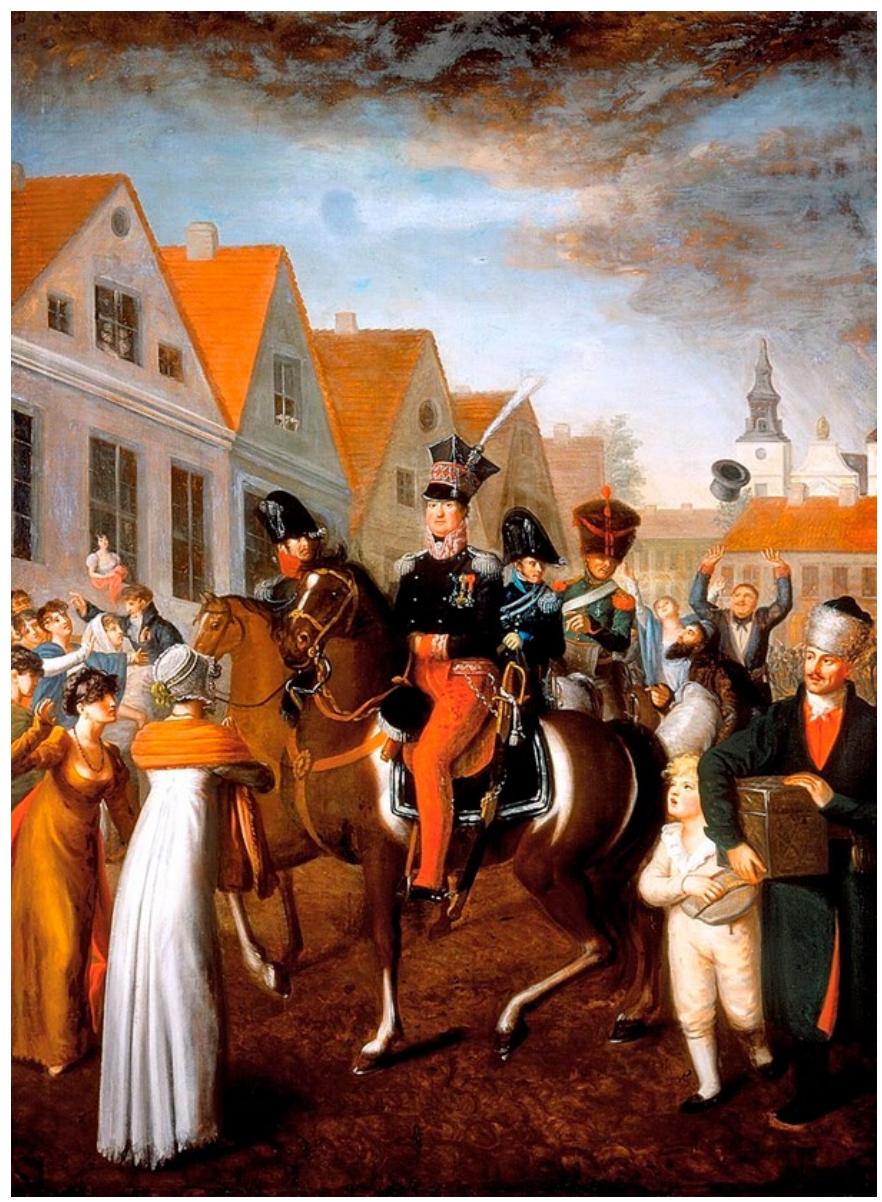

Il. 1. Jan Gładysz, Wjazd Jana Henryka Dąbrowskiego do Poznania, ok. 1809 r. Źródło: wikipedia.pl (dostęp 16 stycznia 2020) 


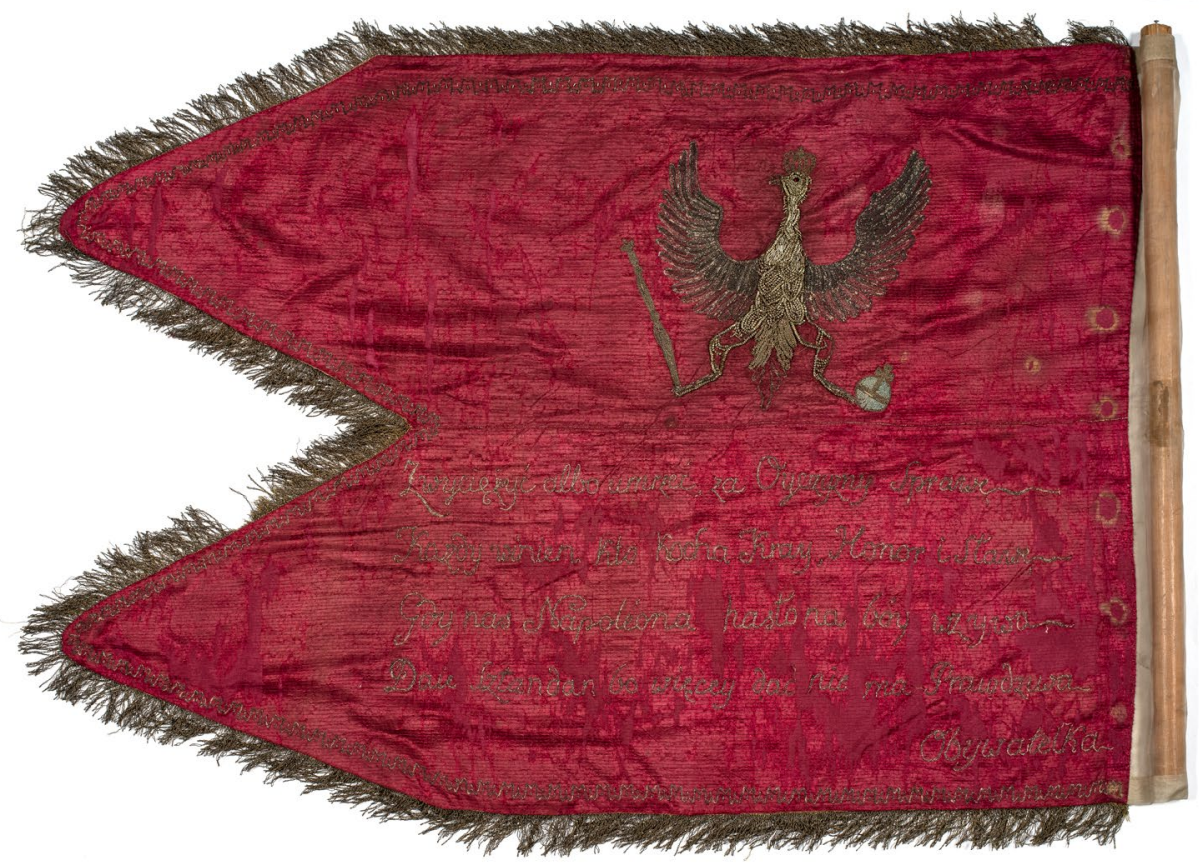

Il. 2. Chorągiew pospolitego ruszenia województwa gnieźnieńskiego, Wielkopolska, 1806 r. awers. Fot. ze zbiorów Muzeum Okręgowego im. Leona Wyczółkowskiego w Bydgoszczy, sygn. MOB H-897. Fot. W. Woźniak 


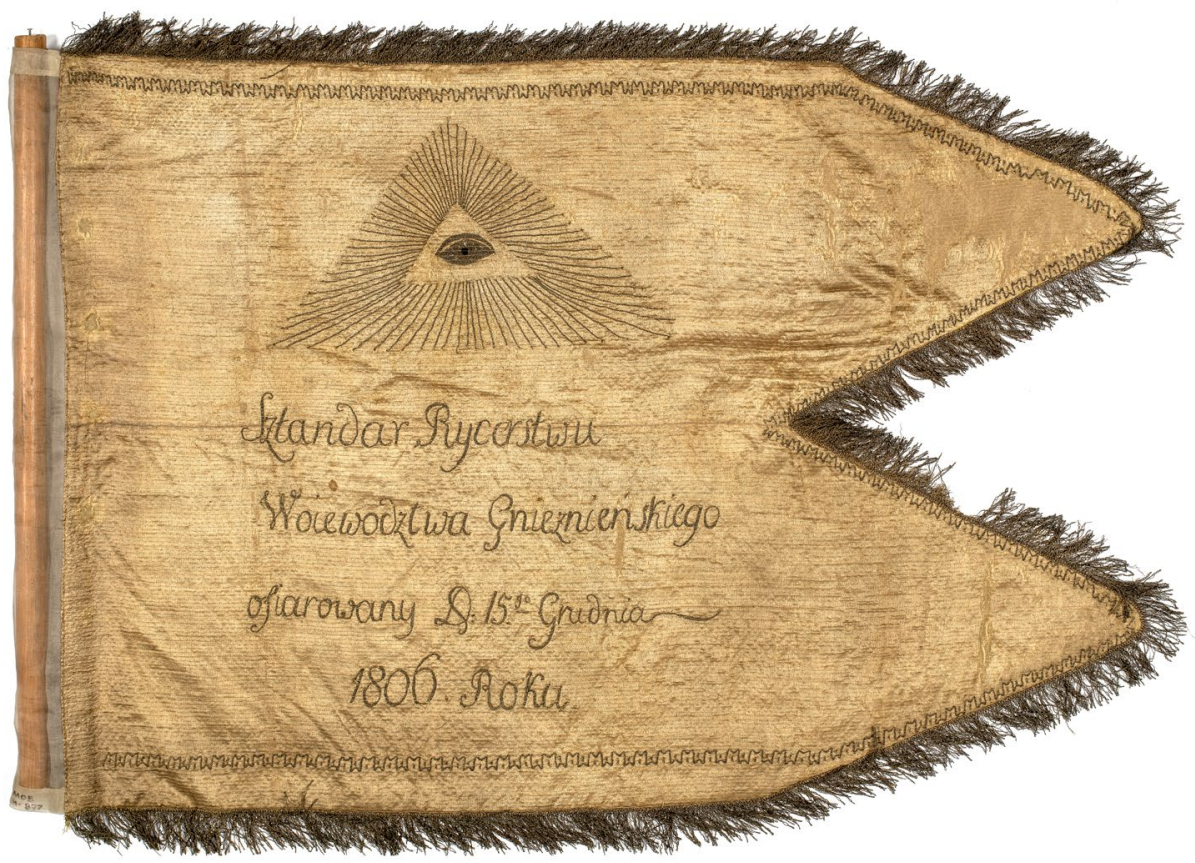

Il. 3. Chorągiew pospolitego ruszenia województwa gnieźnieńskiego, Wielkopolska, 1806 r. rewers. Fot. ze zbiorów Muzeum Okręgowego im. Leona Wyczółkowskiego w Bydgoszczy, sygn. MOB H-897. Fot. W. Woźniak 


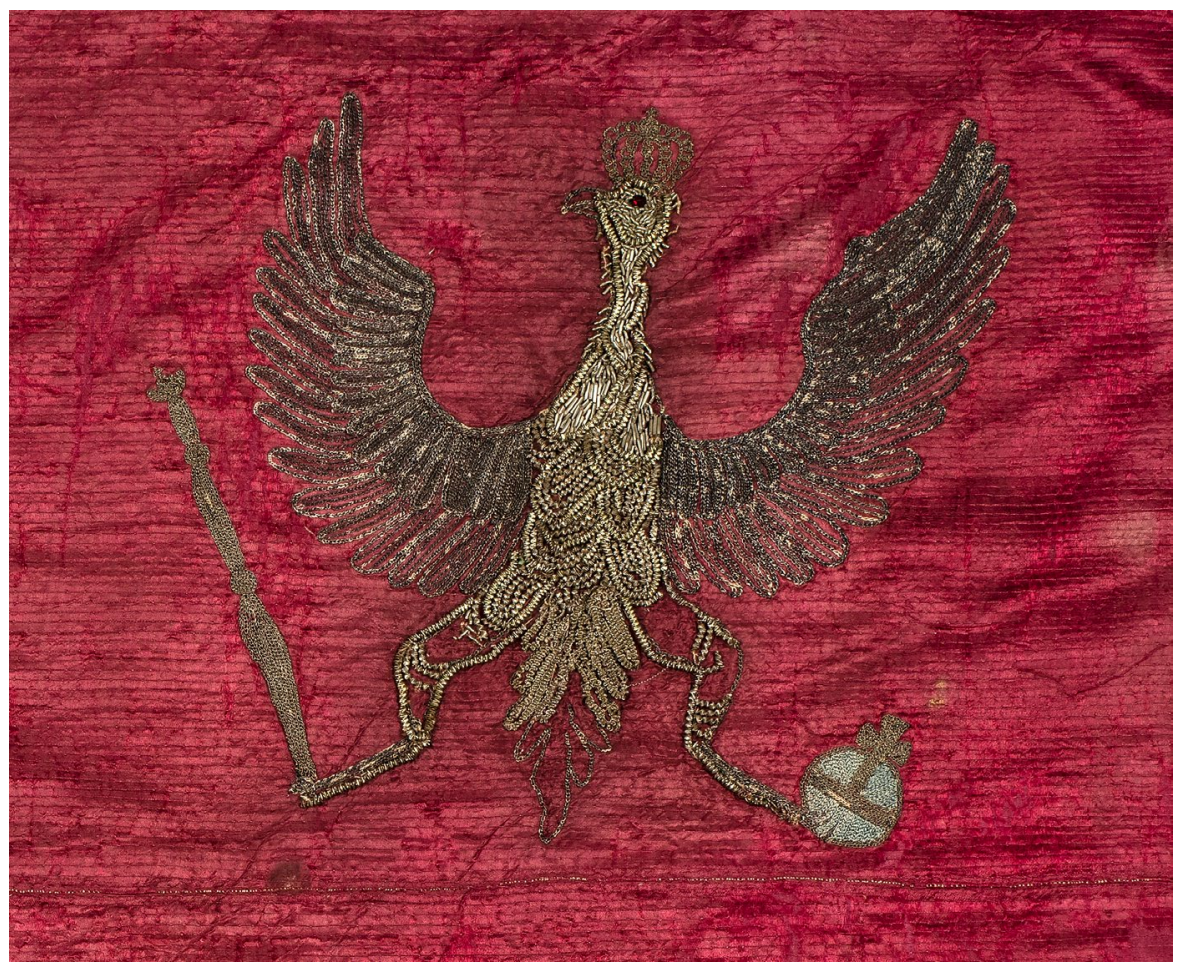

Il. 4. Chorągiew pospolitego ruszenia województwa gnieźnieńskiego, Wielkopolska, 1806 r. Fragment awersu - haftowany orzeł. Fot. ze zbiorów Muzeum Okręgowego im. Leona Wyczółkowskiego w Bydgoszczy, sygn. MOB H-897. Fot. W. Woźniak 


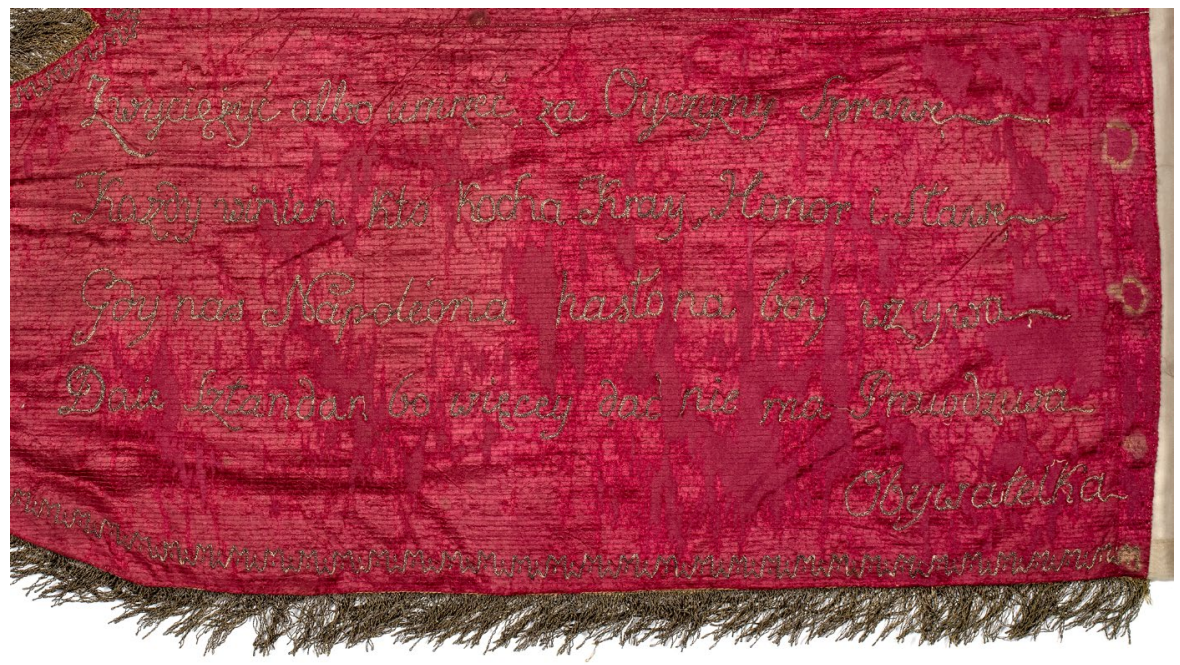

Il. 5. Chorągiew pospolitego ruszenia województwa gnieźnieńskiego, Wielkopolska, 1806 r. Fragment awersu - haftowana inskrypcja. Fot. ze zbiorów Muzeum Okręgowego im. Leona Wyczółkowskiego w Bydgoszczy, sygn. MOB H-897. Fot. W. Woźniak 


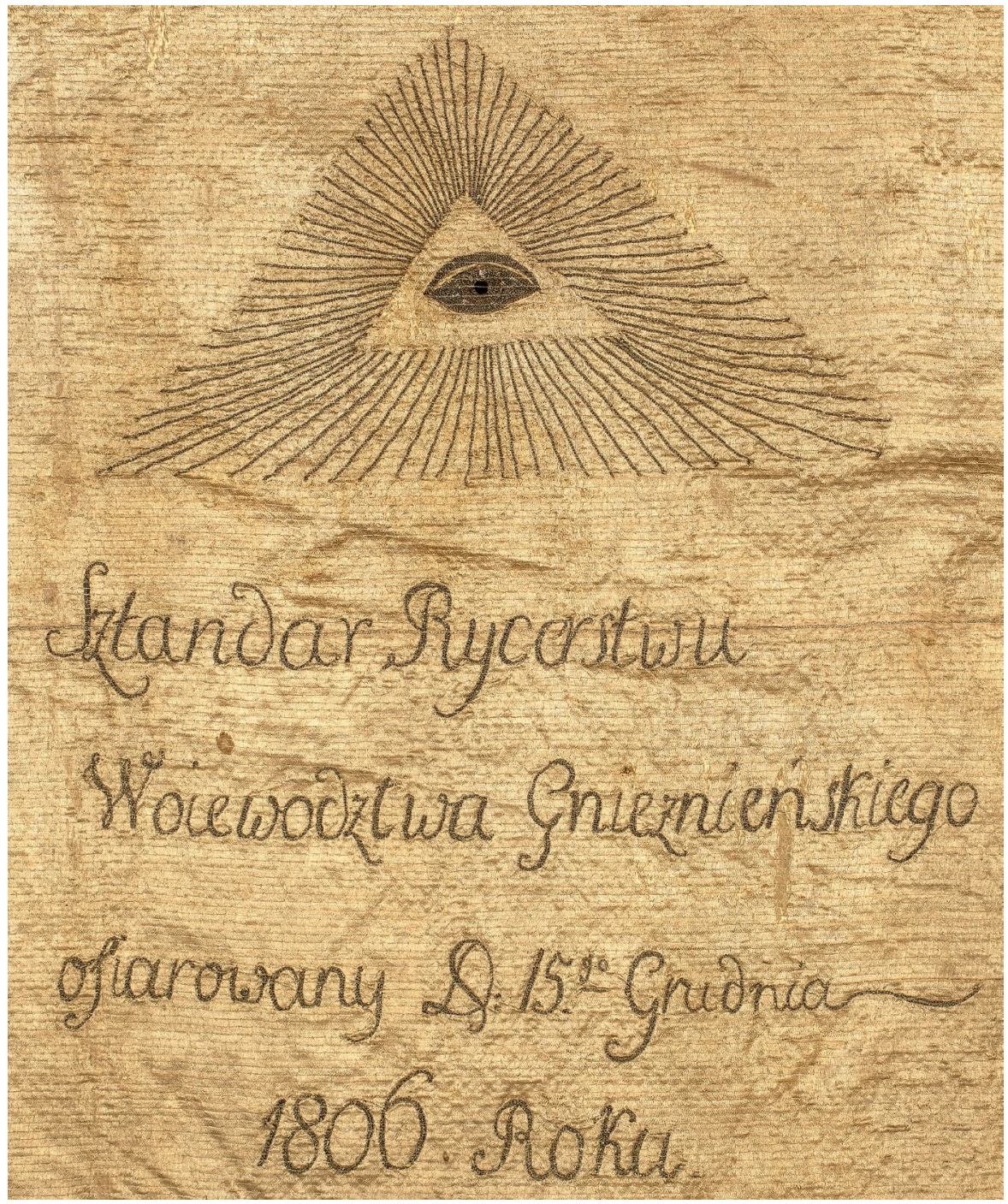

Il. 6. Chorągiew pospolitego ruszenia województwa gnieźnieńskiego, Wielkopolska, $1806 \mathrm{r}$. Fragment rewersu - haftowany motyw Oka Opatrzności oraz inskrypcja. Fot. ze zbiorów Muzeum Okręgowego im. Leona Wyczółkowskiego w Bydgoszczy, sygn. MOB H-897. Fot. W. Woźniak 

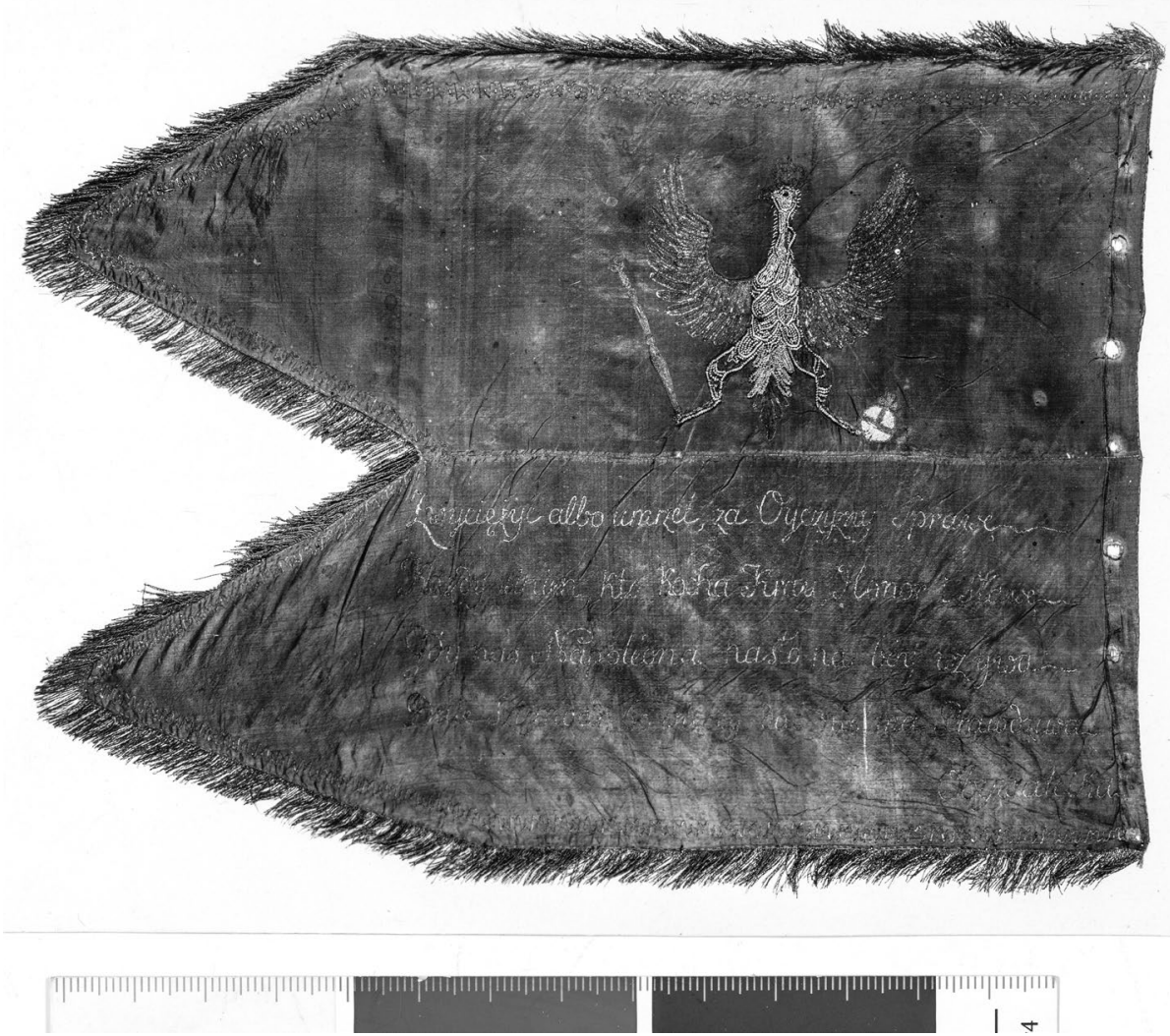

Il. 7. Chorągiew pospolitego ruszenia województwa gnieźnieńskiego, Wielkopolska, 1806 r., stan przed konserwacją, awers. Fot. P. Wiszniewski (przed 1966), ze zbiorów Muzeum Okręgowego im. Leona Wyczółkowskiego w Bydgoszczy, sygn. MOB H/F-2416, reprod. W. Woźniak 


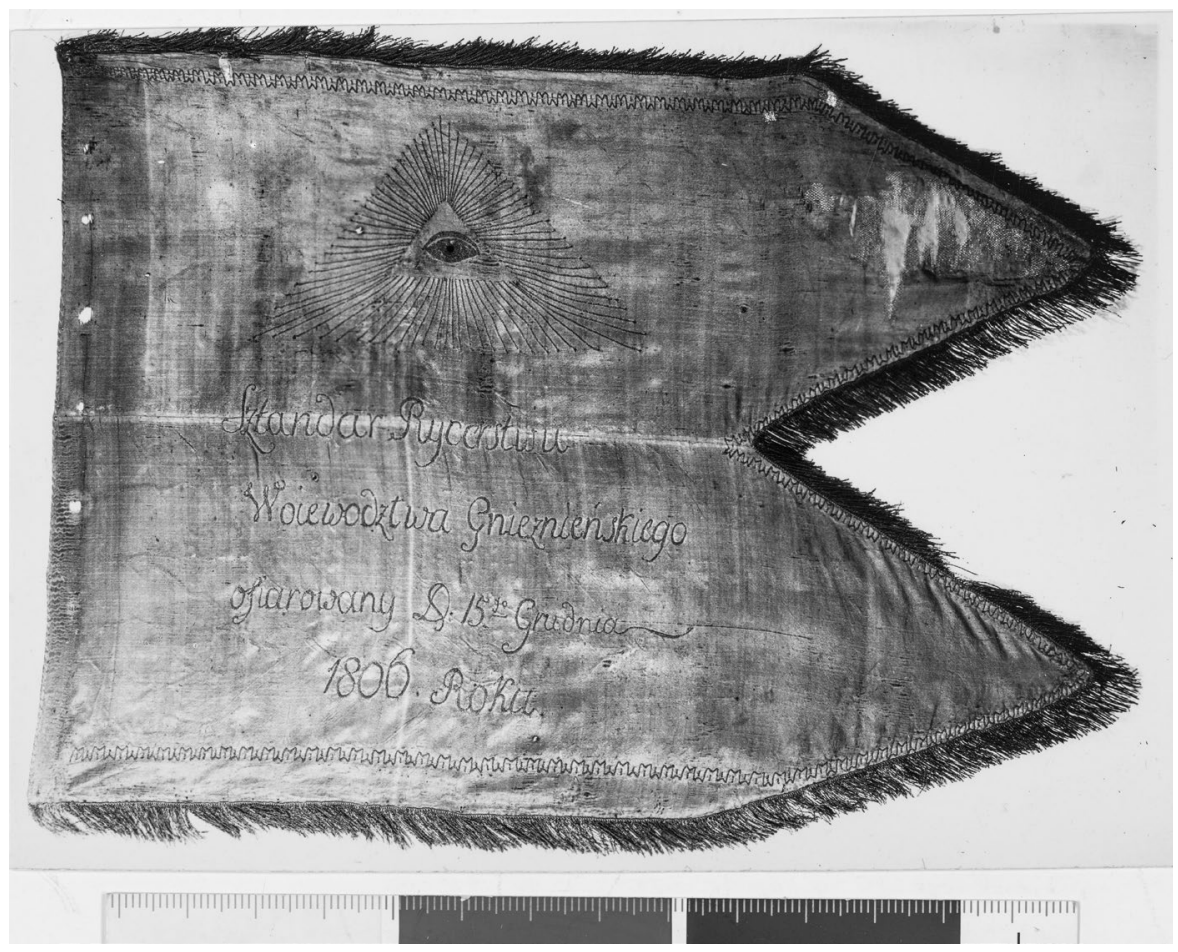

Il.8. Chorągiew pospolitego ruszenia województwa gnieźnieńskiego, Wielkopolska, 1806 r., stan przed konserwacją, rewers. Fot. P. Wiszniewski (przed 1966), ze zbiorów Muzeum Okręgowego im. Leona Wyczółkowskiego w Bydgoszczy, sygn. MOB H/F-2417, reprod. W. Woźniak 


\section{Bibliografia}

\section{Źródła}

Bydgoszcz. Muzeum Okręgowe im. Leona Wyczółkowskiego. Dział Historii, Sztandar Rycerstwu Województwa Gnieźnieńskiego ofiarowany D. 15go Grudnia 1806 roku, nr inw. MOB H-897. Karta naukowa zabytku, oprac. Gabriela Bedrij. Bydgoszcz 1975. Archiwum Wybickiego. T. 2 (1802-1822), zebrał i wydał Adam M. Skałkowski. Gdańsk: Nakładem Towarzystwa Przyjaciół Nauki i Sztuki w Gdańsku z zasiłku Ministerstwa Szkół Wyższych i Nauki, 1950.

\section{Opracowania}

Baszko, Agnieszka. „Organizowanie się kobiet polskich w Poznańskiem na przełomie XIX i XX wieku.” W Działaczki społeczne, feministki, obywatelki... Samoorganizowanie się kobiet na ziemiach polskich do 1918 roku (na tle porównawczym), red. Agnieszka Janiak-Jasińska, Katarzyna Sierakowska, i Andrzej Szwarc, 287-305. Warszawa: Wydawnictwo Neriton, 2008.

Dolczewski, Zygmunt. „Pamiątki napoleońskie w zbiorach poznańskiego Muzeum Sztuk Użytkowych.” Kronika Miasta Poznania 65, nr 3 (1997): 149-160.

Hojka, Zdzisław. Muzeum w Bydgoszczy. Dzieje i zbiory (Od Kościoła Klarysek po Wyspę Młyńską. Muzeum w Bydgoszczy 1923-2008. T. 1, red. Michał Woźniak). Bydgoszcz: Muzeum Okręgowe im. Leona Wyczółkowskiego, 2008.

Hojka, Zdzisław. „Zbiory historyczne.” W Muzeum w Bydgoszczy. Katalog wystawy 26 września-28 grudnia 2008, red. Barbara Chojnacka, Danuta Sójkowska, i Michał Woźniak (Od Kościoła Klarysek po Wyspę Młyńską. Muzeum w Bydgoszczy 1923-2008. T. 2, red. Michał Woźniak), 97-100. Bydgoszcz: Muzeum Okręgowe im. Leona Wyczółkowskiego, 2008.

Jaworski, Rudolf. „Kilka refleksji nad dziejami Wielkopolanek w XIX i na początku XX wieku." W Kobieta i społeczeństwo na ziemiach polskich w XIX wieku, red. Anna Żarnowska i Andrzej Szwarc, 25-35. Warszawa: Wydawnictwo DiG, 1990.

Kallas, Marian. „W czasach Księstwa Warszawskiego.” W Historia Bydgoszczy. T. 1 Do roku 1920, red. Marian Biskup, 419-474. Warszawa-Poznań: Bydgoskie Towarzystwo Naukowe, 1991.

Karolczak, Kazimierz. „Polacy i ziemie polskie po III rozbiorze.” W Franciszek Leśniak, Kazimierz Karolczak, Wielka historia Polski 1696-1815, red. Marian Szulc, 187-234. Kraków: PINNEX, 1998.

Kowalczyk, Anna. Brakująca połowa dziejów. Krótka historia kobiet na ziemiach polskich. Warszawa: Wydawnictwo WAB, 2018.

Macdonell, Archibald Gordon. Napoleon i jego marszałkowie. Tłumaczenie Andrzej Nieuważny. Londyn: Wydawnictwo PULS, $1992^{2}$. 
Nadolska, Anna. „Konspiracja w spódnicy. Bydgoszczanki w wielkopolskim zrywie niepodległościowym 1918/1919.” Kronika Bydgoska 38 (2017): 221-232.

Nadolska, Anna. „Obiekt miesiąca. Chorągiew powstania wielkopolskiego.” Bydgoski Informator Kulturalny 44, nr 11 (2018): 28.

Nadolska, Anna. „Ziemianka w służbie Bydgoszczy. Kulturalna, społeczna i narodowa działalność Stefanii Tuchołkowej na początku XX wieku.” Kronika Bydgoska 39 (2018): 85-102.

Olejnik, Karol. „Rok 1806 w Wielkopolsce.” Kronika Miasta Poznania 65, nr 3 (1997): 49-64.

Pachoński, Jan. Generał Jan Henryk Dąbrowski 1755-1818. Warszawa: Wydawnictwo MON, 1981.

Paczuski, Adam. Gdańsk napoleoński. Oblężenia 1807, 1813. Katalog wystawy 22 lipca-13 sierpnia 2000. Gdańsk: Muzeum Historyczne Miasta Gdańska, 2000.

Satora, Kazimierz. Na tropach wrześniowych sztandarów. Warszawa: Związek Kombatantów RP i Byłych Więźniów Politycznych Warszawa Śródmieście i Fundacja Moje Wojenne Dzieciństwo, 2001.

Sójkowska, Danuta. „Dwudziestolecie międzywojenne (1923-1939).” W Muzeum w Bydgoszczy. Katalog wystawy 26 września-28 grudnia 2008, red. Barbara Chojnacka, Danuta Sójkowska, i Michał Woźniak (Od Kościoła Klarysek po Wyspę Młyńską. Muzeum w Bydgoszczy 1923-2008. T. 2, red. Michał Woźniak), 145-203. Bydgoszcz: Muzeum Okręgowe im. Leona Wyczółkowskiego, 2008.

Staszewski, Janusz. „Organizacja dywizji poznańskiej w 1806 r.” Roczniki Historyczne 9 (1933): 71-99.

Stegmann, Natalia. „Wielkopolskie wzorce kobiecej aktywności społecznej w życiu codziennym kobiet na przełomie XIX i XX wieku.” W Kobieta i kultura życia codziennego. Wiek XIX i XX, red. Anna Żarnowska i Andrzej Szwarc, 363-369. Warszawa: Wydawnictwo DiG, 1997.

Wąsicki, Jan. „Powstanie 1806/1807 roku.” W Dzieje Wielkopolski. T. 2 Lata 1793-1918, red. Witold Jakóbczyk, 45-54. Poznań: Wydawnictwo Poznańskie, 1973.

Wąsicki, Jan. Powstanie 1806 roku w Wielkopolsce. Poznań: Wydawnictwo Poznańskie, 1958.

Wojciak, Jerzy. „Pod pruskim zaborem 1815-1920.” W Ryszard Kabaciński, Wojciech Kotowski, Jerzy Wojciak, Bydgoszcz: Zarys dziejów, red. Ryszard Kabaciński, 93-178. Bydgoszcz: WSiP, 1980.

\section{Artykuły prasowe}

[Piętnastolecie] XV-lecie 16/2 Pułku Ułanów Wielkopolskich 1919-1934. Jednodniówka. Oprac. Franciszek Małek i Czesław Dmochowski. 1934.

„Chorągiew polska z r. 1806”. Dziennik Bydgoski, 29 listopada 1919, 2. 
„Pierwsze posiedzenie zarządu bydgoskiego Koła dla badań nad historią powstania Wlkp z 1918-19 r.” Dziennik Bydgoski, 2 stycznia 1927, 5.

Tuchołkowa, Stefanja. „Pierwsza wystawa prac kobiecych w Bydgoszczy.” Dziennik Bydgoski, 12 grudnia 1917, 2-3.

Tuchołkowa, Stefanja. „Pierwsza wystawa prac kobiecych w Bydgoszczy.” Dziennik Bydgoski, 13 grudnia 1917, 2-3.

\section{Netografia}

Gloger, Zygmunt. „Geografia historyczna ziem dawnej Polski. Województwo Kaliskie i Gnieźnieńskie.” Dostęp 21 listopada 2020. https://literat.ug.edu.pl/glogre/0018. htm

Jabłońska, Anna, i Dorota Matyaszczyk. „Napoleon i jego epoka w Wielkopolsce. XIV Europejskie Dni Dziedzictwa Kulturowego w Wielkopolsce 2006.” Dostęp 16 stycznia 2020. http://wtg-gniazdo.org/upload/opracowania/Napoleon_i_jego_epoka_w_ Wielkopolsce.pdf.

„Kalendarium dziejów oręża polskiego. 7 lipca 1807 Powstanie Księstwa Warszawskiego.” Dostęp 18 lutego 2020. http://www.muzeumwp.pl/kalendarium/07-07/.

Nadolska, Anna. „Niepodległa Polska. 1918 rok.” Dostęp 21 listopada 2020. http://muzeum.bydgoszcz.pl/wystawy/id,257,0,0,Niepodlegla-Polska-1918-rok.

„Weksylologia.” Album Polski, Instytut Heraldyczno-Weksylologiczny. Dostęp 16 stycznia 2020. http://www.albumpolski.pl/IHW_WWW/index.php?act=view\&ktg=27 \&idt=134. 